\title{
Updates in rare and not-so-rare complications of acromegaly: focus on respiratory function and quality of life in acromegaly [version 1; peer review: 3 approved]
}

\author{
Fabienne Langlois (iD), Gabriela M. Suarez², Maria Fleseriu(iD2 \\ ${ }^{1}$ Centre Hospitalier Universitaire de Sherbrooke, 3001 12e Avenue Nord, Sherbrooke, QC, J1H 5N4, Canada \\ 2Pituitary Center, Departments of Medicine and Neurological Surgery, Oregon Health \& Science University, 3303 South Bond \\ Avenue, CH8N, Portland, OR, 97239, USA
}

V1 First published: 29 Jul 2020, 9(Faculty Rev):791
https://doi.org/10.12688/f1000research.22683.1

Latest published: 29 Jul 2020, 9(Faculty Rev):791

https://doi.org/10.12688/f1000research.22683.1

\section{Abstract}

Acromegaly is a complex disease with excessive growth hormone and insulin-like growth factor 1 (IGF-1) causing multisystem effects, particularly cardiovascular, respiratory, and metabolic. Psychological concerns and poor quality of life (QoL) are also major disease consequences. This review is intended for clinicians and focuses on the latest developments related to respiratory and QoL effects of longterm growth hormone excess. Along with biochemical disease control, patient treatment satisfaction and outcomes have become major treatment objectives; current knowledge and tools to evaluate and manage this aspect of the disease are described. Sleep apnea syndrome and other derangements of lung function and apparatus, from pathophysiology to treatment, and evaluation tools and determinants of QoL in patients with acromegaly are discussed.

\section{Keywords}

Acromegaly, growth hormone excess, respiratory complication, sleep apnea, quality of life, patients reported outcome

\section{Open Peer Review}

\begin{tabular}{rrr} 
Approval Status \\
1 & 2 & 3 \\
\hline
\end{tabular}

\section{version 1}

29 Jul 2020

Faculty Reviews are review articles written by the prestigious Members of Faculty Opinions. The articles are commissioned and peer reviewed before publication to ensure that the final, published version is comprehensive and accessible. The reviewers who approved the final version are listed with their names and affiliations.

1. Salvatore Cannavo, University Hospital G. Martino, Messina, Italy

2. Sebastian J Neggers, Erasmus University

MC, Rotterdam, The Netherlands

3. Lucio Vilar, Universidade Federal de

Pernambuco (UFPE), Recife, Brazil

Any comments on the article can be found at the end of the article. 
Corresponding author: Maria Fleseriu (fleseriu@ohsu.edu)

Author roles: Langlois F: Investigation, Writing - Original Draft Preparation, Writing - Review \& Editing; Suarez GM: Investigation, Writing - Original Draft Preparation, Writing - Review \& Editing; Fleseriu M: Conceptualization, Investigation, Methodology, Project Administration, Writing - Review \& Editing

Competing interests: FL and GMS declare that they have no competing interests. As principal investigator, MF has received research support to Oregon Health \& Science University from Novartis, Crinetics, Chiasma, and Ionis and has been an occasional scientific consultant to Novartis, Crinetics, Chiasma, Pfizer, and Ipsen.

Grant information: The author(s) declared that no grants were involved in supporting this work.

Copyright: $\odot 2020$ Langlois $\mathrm{F}$ et al. This is an open access article distributed under the terms of the Creative Commons Attribution License, which permits unrestricted use, distribution, and reproduction in any medium, provided the original work is properly cited.

How to cite this article: Langlois F, Suarez GM and Fleseriu M. Updates in rare and not-so-rare complications of acromegaly: focus on respiratory function and quality of life in acromegaly [version 1; peer review: 3 approved] F1000Research 2020, 9(Faculty Rev):791 https://doi.org/10.12688/f1000research.22683.1

First published: 29 Jul 2020, 9(Faculty Rev):791 https://doi.org/10.12688/f1000research.22683.1 


\section{Introduction}

Acromegaly is a disorder almost exclusively caused by a pituitary growth hormone (GH)-secreting adenoma. The high circulating levels of $\mathrm{GH}$ and resulting insulin-like growth factor 1 (IGF-1) have pleiotropic effects on many organs ${ }^{1}$. Ultimately, acromegaly causes an insidious syndrome that severely impacts patient morbidity and quality of life (QoL). Cardiovascular and respiratory complications are frequent comorbidities and are the main causes of mortality among patients ${ }^{2,3}$. Cancer risk is also increased ${ }^{4}$ and recently cancer has been shown to surpass cardiovascular causes as a main cause of death compared with the general population ${ }^{5,6}$. However, with advances in treatment and thus improved biochemical control, mortality has diminished over the past decade ${ }^{7}$. See Table 1 on multisystem acromegaly complications $s^{2,8-12}$.

Cardiovascular complications and cancer have been extensively reviewed as complications of acromegaly ${ }^{13}$. The focus here is on the latest developments related to respiratory and QoL effects.

\section{Respiratory complications}

Background

Patients with acromegaly have been reported to have a 1.85 times higher risk of developing respiratory diseases versus the

Table 1. Multisystem acromegaly complications.

\begin{tabular}{|c|c|}
\hline \multicolumn{2}{|c|}{ System } \\
\hline \multicolumn{2}{|c|}{ Cardiovascular } \\
\hline $\begin{array}{l}- \\
- \\
- \\
- \\
- \\
-\end{array}$ & $\begin{array}{l}\text { Cardiomyopathy characterized by biventricular hypertrophy or fibrosis or both } \\
\text { Hyperkinetic syndrome } \\
\text { Diastolic or systolic dysfunction or both } \\
\text { Arterial hypertension } \\
\text { Valvulopathies } \\
\text { Arrhythmias } \\
\text { Vascular endothelial dysfunction }\end{array}$ \\
\hline \multicolumn{2}{|r|}{ Musculoskeletal } \\
\hline $\begin{array}{l}- \\
- \\
- \\
-\end{array}$ & $\begin{array}{l}\text { Enlargement/elongation of vertebral bodies } \\
\text { Disrupted trabecular bone architecture and vertebral compression fractures } \\
\text { Thoracic spine kyphoscoliosis } \\
\text { Overgrowth of mandible, malocclusion, and increased teeth spacing } \\
\text { Myopathy, including airway muscle fatigue }\end{array}$ \\
\hline \multicolumn{2}{|c|}{ Metabolic } \\
\hline $\begin{array}{l}- \\
- \\
-\end{array}$ & $\begin{array}{l}\text { Insulin resistance and diabetes mellitus } \\
\text { Dyslipidemia: hypertriglyceridemia and low high-density lipoprotein cholesterol } \\
\text { Hyperandrogenemia with a polycystic ovary syndrome-like effect } \\
\text { Hypertrichosis }\end{array}$ \\
\hline \multicolumn{2}{|c|}{ Respiratory } \\
\hline $\begin{array}{l}- \\
- \\
- \\
- \\
- \\
- \\
-\end{array}$ & $\begin{array}{l}\text { Upper airway narrowing, including tracheal stenosis and tortuosity } \\
\text { Macroglossia } \\
\text { Tracheo-bronchomegaly } \\
\text { Thickening of true and false vocal cords } \\
\text { Increased lung volume } \\
\text { Possible decreased lung compliance } \\
\text { Small airway obstruction } \\
\text { Obstructive and central sleep apnea }\end{array}$ \\
\hline \multicolumn{2}{|c|}{ Psychological } \\
\hline $\begin{array}{l}- \\
- \\
-\end{array}$ & $\begin{array}{l}\text { Emotional lability } \\
\text { Social withdrawal } \\
\text { Distorted body image } \\
\text { Diminished quality of life }\end{array}$ \\
\hline \multicolumn{2}{|c|}{ Gastrointestinal } \\
\hline- & $\begin{array}{l}\text { Increased colonic polyps } \\
\text { Dolichocolon }\end{array}$ \\
\hline
\end{tabular}


general population ${ }^{14}$. One of the most common complications of acromegaly is obstructive sleep apnea (OSA); the risk is approximately 10 -fold in acromegaly compared with the general population ${ }^{15-17}$. OSA can exacerbate cardiovascular dysfunction and is an important contributor to impaired QoL and eventually mortality ${ }^{18}$. Lesser-known facets of acromegaly-induced respiratory complications affect pulmonary function, oximetry, and exercise capacity ${ }^{13,19}$. Excess $\mathrm{GH}$, on the surface, would seem to be beneficial to physical performance; however, it can also have deleterious effects and contribute to significant fatigue and inability to sustain similar workloads compared with controls $\mathrm{s}^{19,20}$. Overall, the mortality rates from respiratory causes are three times higher when compared with that of the general population ${ }^{21-23}$ and contribute to up to one fifth of acromegaly-related deaths ${ }^{24,25}$.

\section{Pathophysiology}

Mechanisms by which acromegaly is associated with respiratory complications are not clearly understood. However, there are several proposed mechanisms by which $\mathrm{GH}$ can alter lung anatomy; the main hypotheses are as follows:

1. Upper respiratory airways. High GH/IGF-1 can lead to deformities of facial bones, hypertrophy of the pharyngeal and laryngeal cartilages, and soft tissue thickening and macroglossia, which ultimately can lead to inspiratory collapse of the hypopharynx, especially during sleep $\mathrm{p}^{2,14,26-28}$. Also, generalized tissue edema, related to high sodium and volume reabsorption by the kidney, which contributes to upper airway narrowing, may be observed in patients with acromegaly ${ }^{29,30}$. Ultimately, external compression can occur because of goiter or accumulation of fat and contribute to tracheal deviation, tortuosity, and sometimes stenosis $^{31}$.

2. Lung volumes. GH stimulates lung growth by increasing the number or size of alveoli (or both) ${ }^{14,32,33}$. Data on histopathology of human lungs in patients with acromegaly are lacking, and clinical data from pulmonary function tests sometimes render conflicting results. In general, increased total lung volumes are measured by total lung capacity, vital capacity, and residual volumes, all of which can be 110 to $160 \%$ of a predicted value $^{26,34-39}$. This is related to the direct effect of GH/IGF-1 inducing alveoli hyperplasia, alveoli hypertrophy, or an increase in alveoli number or a combination of these ${ }^{26,34}$. Increased lung mass has also been objectively measured by computed tomography (CT) densitovolumetry; active acromegaly compared with controls revealed a $25 \%$ mass increase: $885 \mathrm{~g}$ versus $696 \mathrm{~g}(P=0.017)^{37}$.

3. Thoracic musculature. GH and IGF-1 exert proliferative but also degenerative effects on smooth muscle, inducing respiratory muscle dystrophia. Myopathy is evident on pathology as muscle fiber degeneration and abnormal collagen are observed $^{40,41}$. These findings translate to enhanced muscle fatigue, as demonstrated in a murine model with effects on sternohyodal muscle ${ }^{42}$.

4. Thoracic bone changes. The axial skeleton is affected in up to $60 \%$ of patients, and changes include thickening of soft and cartilaginous tissues, rib cage deformity, formation of osteophytes, and abnormal trabecular bone microarchitecture leading to vertebral fractures and kyphoscoliosis ${ }^{38}$.

5. Diffusing capacity. Diffusing capacity of the lung for carbon monoxide (DLCO) can also be altered. Some studies reported a lower $\mathrm{DLCO}^{27}$, most showed neutral diffusing capacity $^{26,27,34,35,38,43}$, and some found an increased $\operatorname{DLCO}^{44,45}$. Higher lung volumes could lead to an increase in DLCO; therefore, diffusing capacity corrected for alveolar volume is likely to be normal in patients with acromegaly ${ }^{46}$.

6. Lung compliance. Lung elasticity may also change due to excess GH/IGF-1. Decreased lung recoil might be explained by elevated peripheral rib cage resistance caused by hypertrophic muscles and rib cage or caused by obesity ${ }^{26}$ but could also be related to a higher alveoli size $^{43}$. Some series did not demonstrate a change (ref 34) in lung elasticity and one (ref 43) showed that patients with acromegaly had higher lung distensibility, which was partially reversible after treatment ${ }^{34,43}$. Various components of lung compliance may be differently affected in the disease and may explain the heterogeneity of results.

7. Obstructive disease. Small airway obstruction is evident on the basis of a reduced maximum expiratory flow after $75 \%$ of forced vital capacity had been exhaled (FEF75). Moreover, more than half of patients had clinically important reductions ( $<80 \%$ of predicted value) in FEF75 $5^{38,47,48}$. Up to $60 \%$ of air trapping causing ventilation perfusion mismatches was reported ${ }^{38}$. This small airway obstruction might be due to increased thickness or tortuosity of the bronchial wall, increased lung volumes, or vascular congestion or a combination of these ${ }^{38}$.

8. Bronchiectasis was also noted on high-resolution $\mathrm{CT}$ but might not be more prevalent than what is observed in healthy subjects $^{49}$.

\section{Diagnosis and management}

Sleep apnea in patients with acromegaly. In different series, sleep apnea affects up to $80 \%$ of patients and represents a 10 -fold increased risk compared with the general population ${ }^{11,13,50}$. A main symptom of OSA is daytime sleepiness caused by repeated micro-arousal due to hypoxemic events during sleep ${ }^{50}$. Acromegaly is predominantly associated with OSA, caused by upper airway obstruction ${ }^{2,18,51,52}$. However, central sleep apnea also occurs, as about $30 \%$ of patients with acromegaly have a central sleep apnea component ${ }^{53-56}$. Pathogenesis remains controversial but might be directly GH-mediated or related to associated cardiomyopathy ${ }^{56,57}$. Excess $\mathrm{GH}$ is associated with central inhibition of the breathing center and may lower the ventilatory response of the respiratory center to carbon dioxide, resulting in a temporary cessation of the respiratory center and respiratory efforts ${ }^{56}$.

Other factors, notably obesity, concomitant hypothyroidism, and treatment of hypogonadism, also play a role in $\mathrm{OSA}^{13}$. 
Hypogonadism in male patients with acromegaly and OSA is frequent. Hormonal replacement should be undertaken with caution, especially in cases of severe untreated OSA since there is some evidence that testosterone might deteriorate $\mathrm{OSA}^{58}$.

If sleep apnea is left untreated, it can lead to fatigue, daytime sleepiness, hypogonadism, arterial and pulmonary hypertension, ischemic heart disease, right ventricular failure, cerebrovascular accidents, life-threatening arrhythmias, poor QoL, and cognitive dysfunction ${ }^{14,18,50,52,59,60}$. Usual predictors such as age, male sex, neck circumference, and body mass index (BMI) are factors associated with the onset and severity of OSA, but finger circumference is an additional predictor specific to acromegaly ${ }^{11,18,61-64}$. Use of the Epworth Sleepiness Scale or the STOP-Bang (snoring, tiredness, observed apnea, high blood pressure, BMI, age, neck circumference, and male sex) questionnaire can help identify patients, in the general population, but more studies are needed in patients with acromegaly, and polysomnography remains key for $\operatorname{diagnosis}^{18,50,65}$.

It is still a matter of debate whether OSA severity is associated with disease activity or disease duration or both ${ }^{66,67}$. Some reversibility of OSA may be observed once biochemical control is achieved, but a recent meta-analysis confirms that the prevalence of OSA in patients with controlled acromegaly is similar to that in patients with uncontrolled acromegaly ${ }^{68}$. Nonetheless, acromegaly patients who underwent treatment have been shown to have improvement in both central and peripheral component of sleep-breathing control, especially by reducing soft tissue swelling and macroglossia ${ }^{14,18,54,61,69}$. However, changes in bones and cartilaginous structures affecting upper airway anatomy may be irreversible ${ }^{13}$, and even worsening or de novo OSA, partly related to weight gain after cure, may occur ${ }^{16,18}$.

In general, prospective studies suggest that more than $50 \%$ of patients with controlled acromegaly continue to have persistent OSA $^{13,14,55}$. Most improvement is attained in the first year after treatment ${ }^{55}$. Pituitary surgery has been reported to improve sleep apnea and decrease the frequency of apneic and hypopneic episodes by 50 to $60 \%$ in a surgically cured cohort ${ }^{39,62}$. Medical treatment also leads to improvement in apnea-hypopnea index (AHI), as indices of oxygen desaturation, sleep quality, and subjective sleepiness improved after 6 months of octreotide treatment in approximately half of cases $^{70}$. Intriguingly, AHI changes in patients do not always correlate with $\mathrm{GH}$ or IGF-1 levels, and other factors such as age, sex, and smoking also prevail ${ }^{71}$. Interestingly, one factor influencing AHI is weight, as OSA did not improve and may occur de novo in patients who gained weight after treatment ${ }^{72}$.

Overall, evaluating patients with acromegaly for OSA at diagnosis is mandatory ${ }^{73}$. A diagnostic procedure such as polysomnography or home sleep apnea testing should be ordered if clinical suspicion exists. Screening of every patient could be done since the pre-test probability is very high. Follow-up by periodic re-evaluation of OSA is warranted at least 1 year after successful treatment ${ }^{74}$. Attention to weight gain and physiological hormonal replacement in the post-treatment period may help improve OSA ${ }^{13}$.

Pulmonary function abnormalities. No definite management concerning respiratory insufficiency exists. Biochemical remission does not seem to improve lung function parameters in most patients ${ }^{39}$. Pulmonary function tests (spirometry and diffusing capacity) may be ordered in a patient with unexplained shortness of breath or decreased exercise capacity, but cardiovascular dysfunction may also be a cause. No specific treatment has been proposed and tested in this population, but either inhalotherapy or other treatment modalities may be individualized according to findings.

\section{Quality of life}

Acromegaly is a chronic disease with multiple physical and psychological complications that carry a significant disease burden. Most patients have joint pain, headaches, low energy and libido, and morphological changes such as craniofacial deformation. These changes may not be completely reversible after treatment and can negatively affect $\mathrm{QoL}^{75}$. The comorbidities and active symptomatology also negatively affect patient productivity and entail high costs related to sick leave, unemployment, or disability ${ }^{76,77}$. Other factors, such as cognitive dysfunction and restless leg syndrome, are more prevalent in patients with acromegaly and are associated with poor QoL $^{78,79}$. Moreover, diagnosis delay and acceptance of the disease could be challenging for patients ${ }^{80,81}$. Figure 1 (Gadelha et al.) summarizes the factors affecting QoL in acromegaly ${ }^{13}$.

QoL is defined as the patient's perception of his or her physical and mental health, cognitive function, anxiety, depression, and subjective feelings of energy levels. QoL is considered an important endpoint in the evaluation of patients with acromegaly. It can be measured with questionnaires designed for use in the general population or aimed at specific disease dimension conditions, such as disease-generated or -specific questionnaires like the Acromegaly Quality of Life (AcroQoL) questionnaire $^{75,82}$. Table 2 presents brief details of the following questionnaires: the Symptom Questionnaire ${ }^{83,84}$, Signs and Symptoms Score ${ }^{85,86}$, the Patient-Assessed Acromegaly Symptom Questionnaire ${ }^{85,86}$, Short-Form Health Survey (SF-36) ${ }^{87-89}$, the Multidimensional Fatigue Inventory (MFI-20) $)^{90,91}$, the Nottingham Health Profile ${ }^{92,93}$, Health-Related Quality of Life ${ }^{12,94}$, Psychological General Well-Being ${ }^{82,95}$, the Hospital Anxiety and Depression Scale ${ }^{96,97}$, the AcroQoL Questionnaire ${ }^{75,82,96,98}$, and the Acromegaly Treatment Satisfaction Questionnaire (Acro-TSQ) ${ }^{99,100}$.

A systematic review confirmed that AcroQoL scores are significantly impaired in patients with acromegaly ${ }^{101}$. Geraedts et al. showed that the most significant factors associated with poor QoL were depression and higher $\mathrm{BMI}^{102}$. Other predictors have been inconsistently identified; longer disease duration, painful syndrome (musculoskeletal or headache), diabetes, older age, female gender, having received treatment with radiotherapy, and becoming GH-deficient after treatment ${ }^{75,102,103}$. 


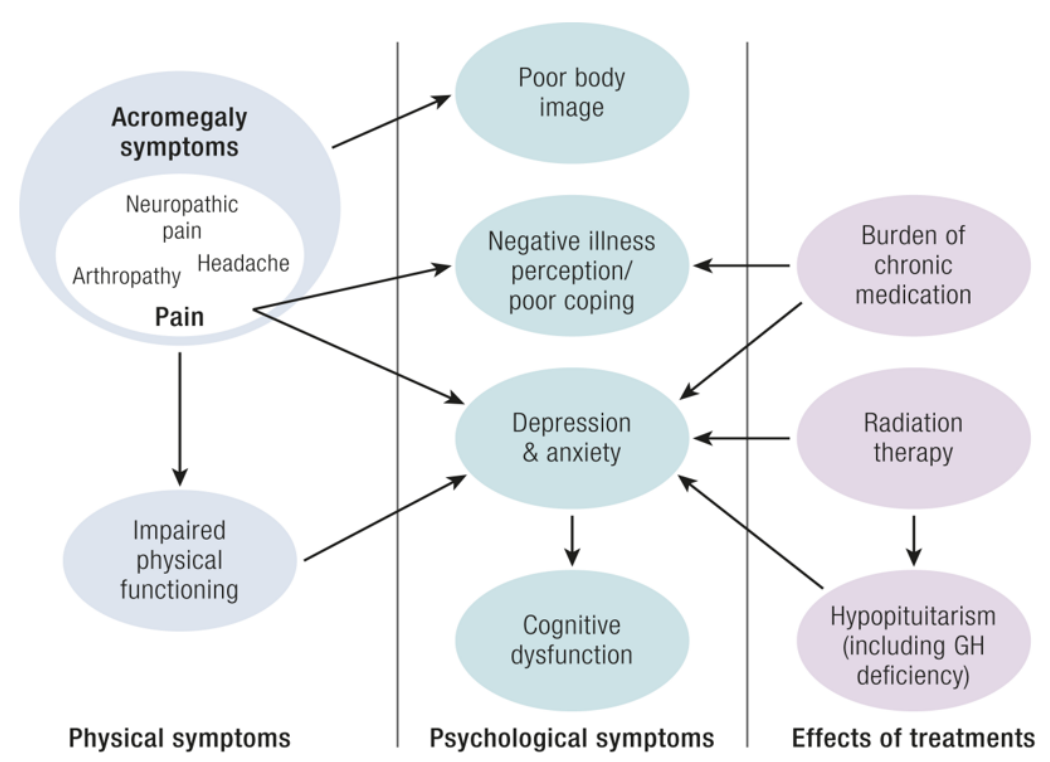

Figure 1. Factors affecting quality of life in patients with acromegaly. [๑ 2019 Illustration Presentation ENDOCRINE SOCIETY]. GH, growth hormone. The figure was reproduced from Gadelha MR et al., Systemic Complications of Acromegaly and the Impact of the Current Treatment Landscape: An Update, Endocrine Reviews, 2019, Volume 40, Issue 1, Pages 268-33213 by permission of the Endocrine Society.

Successful therapy might improve QoL but may not normalize QoL completely, even after biochemical cure c5,104-107. $^{70}$. Indeed, QoL has been shown to be severely impaired years after successful treatment in patients with acromegaly compared with the general population ${ }^{104,108,109}$.

\section{Quality of life after treatment}

Numerous studies have looked at the impact of different treatment modalities in first- or second-line therapies. Pituitary surgery compared with medical treatment seems superior in improving QoL in patients with acromegaly ${ }^{101}$ as in other types of pituitary tumor ${ }^{110}$. A French study found that patients who underwent surgery had a better QoL than if they had received medical treatment only $(65 \pm 18 \%$ versus $54 \pm 14 \%$, $P=0.009$ ), and investigators concluded that neurosurgery was associated with greater improvement in QoL when compared with medical therapy alone ${ }^{111}$. Overall, greater GH suppression could be attained with surgery than with somatostatin receptor ligand (SRL) injections ${ }^{112}$. Indeed, patients with remission after surgery could avoid medication side effects and consequences of suboptimal biochemical control.

Types of medical therapy used rendered heterogeneous results on QoL, see Table $3^{113-125}$. Some studies with first-line SRL injections in treatment-naïve patients show improved QoL in patients who received long-acting lanreotide ${ }^{114,115}$, but the results were controversial ${ }^{106,116,124,126}$. On the other hand, a multicenter study showed that two thirds of patients controlled on SRL injections reported ongoing incommoding acromegaly symptoms ${ }^{127}$. In that study, gastrointestinal disturbances were very frequent (73\%); this was possibly related to SRL side effects or disease activity itself ${ }^{127}$. A new questionnaire, Acro-TSQ, was developed to evaluate QoL specifically in patients who received injectable SRLs and provides further insight ${ }^{99}$.

Changing long-acting release (LAR) octreotide to pasireotide LAR did not improve QoL even if further disease control was obtained $^{122}$. On the contrary, in one study, adding pegvisomant to SRLs led to improvement of QoL and clinical symptoms despite not showing any change in circulating IGF-1 ${ }^{124,128}$, but studies with a similar design were negative ${ }^{125,129}$. This might suggest that improving biochemical control with a favorable safety profile and ease of administration would improve patient QoL. However, further research is required in this area.

Radiotherapy is usually indicated for patients with more aggressive cases of acromegaly, in particular those with residual disease after surgery and medical therapy ${ }^{75}$. Patients who underwent radiotherapy reported that it had a negative influence on energy, pain, social isolation, physical fatigue, and activity and motivation measured with the MFI-20 ${ }^{130}$. During follow-up, the scores in 5 out of 26 QoL subscales significantly worsened $^{75,90}$. This might be due to a direct brain effect induced by radiotherapy, by new hormonal deficits, by delay in biochemical control of excess $\mathrm{GH}$, or by the disease severity itself or by a combination of these factors. Nonetheless, the results are important to take in account in the decision to irradiate a tumor, especially in young patients.

Quality of life in acromegaly patients who become growth hormone-deficient after treatment

Development of GH deficiency after treatment of acromegaly has also been shown to affect QoL. Wexler et al. found that the mean scores on the Quality of Life Adult Growth Hormone 


\section{Table 2. Questionnaires to evaluate quality of life in acromegaly.}

\section{Questionnaires to evaluate quality of life in acromegaly}

Symptom Questionnaire

Signs and Symptoms Score (SSS)

\section{Description}

The Symptom Questionnaire is a 92-item questionnaire assessing four scales: anxiety, depression, somatic symptoms, and anger/hostility. Subjects indicate the frequency of symptoms in the past week on a scale from absent to very often. Higher scores indicate greater symptom severity. This questionnaire may be more sensitive in discriminating between distress levels than other tests ${ }^{83,84}$.

The SSS questionnaire is designed specifically to measure acromegaly-related signs and symptoms such as headache, perspiration, joint pain, fatigue, and soft tissue swelling. Each of those five questions is evaluated by a score from 0 (absent) to 8 (severe) for a maximum of 40 indicative, very severe clinical manifestations ${ }^{85,86}$.

Patient-Assessed Acromegaly Symptom Questionnaire (PASQ)

Short-Form Health Survey (SF-36)

The PASQ is a disease-specific questionnaire composed of seven questions. The first six questions evaluate physical symptoms (headache, perspiration, joint pain, fatigue, soft tissue swelling, and paresthesia of the extremities) and a seventh question evaluates overall well-being. Each aspect is scored from 0 to 8; a lower score reflects low disease impact and a higher score reflects a more severe disease burden ${ }^{85,86}$

The SF-36 is a validated self-administered questionnaire that evaluates physical and psychological symptoms and their impact on daily life. Eight domains are explored: physical functioning, role limitations due to physical functioning, general health perception, pain, vitality, emotional well-being, role limitations due to emotional health, and social functioning. SF-36 consists of 36 questions answered with either "yes/ no" responses or scaled responses ranging from three options ("yes, limited a lot", "yes, limited a little", or "no, not limited at all") to six options ("all of the time", "most of the time", "a good bit of the time", "some of the time", "a little of the time", or "none of the time"). Higher scores indicate a better quality of life ${ }^{87-89}$

Multidimensional Fatigue Inventory (MFI-20)

Nottingham Health Profile

$(\mathrm{NHP})$

The MFI-20 contains 20 statements to assess fatigue. There are five different dimensions of fatigue and each contains four items. The dimensions are general fatigue, physical fatigue, reduced activity, reduced motivation, and mental fatigue. Items are rated on a scale from 0 (absent) to 5 (extremely). A higher score indicates more fatigue experienced $\mathrm{d}^{90,91}$

The NHP is frequently used in patients with pituitary disease to assess general well-being and QoL. This survey consists of 38 "yes/no" questions that are subdivided into six scales assessing impairments: pain (eight items), energy level (three items), sleep (five items), emotional reactions (nine items), social isolation (five items), and disability/functioning (i.e., physical mobility) (eight items). A higher score is associated with more impairment ${ }^{22,93}$.

Health-Related Quality of Life (HRQoL)

This is a 15-item, standardized, self-administered HRQoL instrument that can be used both as a profile and as a single-index score measure. The 15 items evaluated are moving, seeing, hearing, breathing, sleeping, eating, speech, eliminating, usual activities, mental function, discomfort and symptoms, depression, distress, vitality, and sexual activity. For each item, the patient chooses one of the five levels that best describes his or her state of health at that moment ${ }^{12,94}$

The Psychological General Well-Being (PGWB)

The PGWB Index is a 22-item questionnaire that evaluates six subscales: anxiety, depressed mood, positive well-being, self-control, general health, and vitality. Each item has six questions, which are scored from 0 to 5. A score of 110 represents a perfect QOL ${ }^{82,95}$

Hospital Anxiety and Depression Scale (HADS)

This is a 14-item questionnaire evaluating anxiety and depression. Each item is scored on a 4-point scale. Scores range from 0 to 21 for the anxiety and depression subscale and from 0 to 42 for the total score. Higher scores indicate higher levels of anxiety and depression ${ }^{96,97}$

AcroQoL Questionnaire

The AcroQoL Questionnaire has been used and validated in randomized clinical trials, leading to a better understating of the specific impairments in acromegaly. This questionnaire consists of 22 questions that evaluate physical and psychological dimensions. Answers are recorded on a scale from 1 (always or completely agree) to 5 (never or completely disagree). The maximum score of 110 reflects best possible QoL and is quoted as a percentage (e.g., 100\%). The 22 items evaluate physical symptoms such as pain and fatigue and psychological function, such as impact on appearance, performance, and personal relationships ${ }^{75,82,96,98}$.

Acromegaly Treatment Satisfaction Questionnaire (Acro-TSQ)
This questionnaire is a novel tool to simultaneously evaluate patient satisfaction on disease and treatment with somatostatin receptor ligand. It measures treatment effectiveness, symptom burden, treatment side effects, convenience of treatment, and overall satisfaction over the past 4 weeks 99,100 .
Deficiency Assessment (QoL-AGHDA), SF-36, and Symptom Questionnaire Depression showed significantly impaired QoL in the GH-deficient group when compared with the GH-sufficient group. Peak GH levels after GH-releasing hormone-arginine stimulation were inversely associated with QoL-AGHDA scale scores $(\mathrm{R}=-0.53 ; P=0.0005)$ and Symptom Questionnaire Depression subscale scores $(\mathrm{R}=-0.35 ; P=0.031)^{131}$.
Acromegaly-related pain and quality of life

Osteoarthritis is a major cause of pain in acromegaly. Although improvement of hypertrophic articular and periarticular issues has been noted with normalization of GH/IGF-1, ${ }^{132}$ degenerative joint disease is somewhat irreversible, and arthralgias might not resolve even after biochemical remission ${ }^{133-135}$. Fifty-eight patients with acromegaly were evaluated with the 
Table 3. Prospective studies on effect of pharmacotherapy on quality of life.

\begin{tabular}{|c|c|c|c|c|c|c|c|}
\hline Therapy & Publication & $\begin{array}{l}\text { Number } \\
\text { of } \\
\text { patients }\end{array}$ & $\begin{array}{l}\text { Follow-up, } \\
\text { Weeks }\end{array}$ & $\begin{array}{l}\text { Disease status } \\
\text { (for majority of } \\
\text { patients) }\end{array}$ & $\begin{array}{l}\text { Medical treatment in } \\
\text { control group }\end{array}$ & $\begin{array}{l}\text { Scales } \\
\text { used }\end{array}$ & $\begin{array}{l}\text { Effect on } \\
\text { quality of } \\
\text { life }\end{array}$ \\
\hline Lanreotide Autogel & Sonino et al. (1999) ${ }^{113}$ & 10 & 8 & Uncontrolled & $\begin{array}{l}\text { Octreotide LAR or } \\
\text { bromocriptine }\end{array}$ & $\begin{array}{l}\text { KSQ, } \\
\text { CSKSLPP }\end{array}$ & $\uparrow \uparrow$ \\
\hline Lanreotide Autogel & Lombardi et al. (2009) $)^{114}$ & 51 & 52 & Uncontrolled & Treatment naïve & NHP & $\uparrow \uparrow$ \\
\hline Lanreotide Autogel & Caron et al. (2016) & 90 & 48 & Uncontrolled & Octreotide LAR & $\begin{array}{l}\text { AcroQoL, } \\
\text { PASQ }\end{array}$ & $\uparrow \uparrow$ \\
\hline Lanreotide Autogel & Schopohl et al. (2011) & 37 & $26-52$ & Controlled & Octreotide LAR & AcroQoL & $\leftrightarrow$ \\
\hline $\begin{array}{l}\text { Octreotide LAR } \\
\text { intensification }\end{array}$ & Mangupli et al. (2014) $)^{117}$ & 28 & 24 & Uncontrolled & $\begin{array}{l}\text { Treatment naïve or } \\
\text { Octreotide LAR }\end{array}$ & AcroQoL & $\uparrow \uparrow$ \\
\hline Octreotide LAR & Chin et al. (2015) & 58 & 24 & Uncontrolled & Treatment naïve & AcroQoL & $\uparrow$ \\
\hline Octreotide LAR & Ghigo et al. (2009) ${ }^{119}$ & 57 & 48 & Uncontrolled & Treatment naïve & $\begin{array}{l}\text { AcroQoL, } \\
\text { SSS }\end{array}$ & $\uparrow \uparrow$ \\
\hline $\begin{array}{l}\text { Octreotide LAR } \\
\text { every } 6 \text { weeks }\end{array}$ & Biermasz et al. (2003) $)^{120}$ & 14 & 36 & Controlled & $\begin{array}{l}\text { Octreotide LAR } \\
\text { every } 4 \text { weeks }\end{array}$ & $\mathrm{NHP}$ & $\leftrightarrow$ \\
\hline $\begin{array}{l}\text { Octreotide LAR or } \\
\text { Lanreotide Autogel } \\
\text { intensification }\end{array}$ & Dal et al. (2018) & 61 & 52 & Controlled & $\begin{array}{l}\text { Octreotide LAR or } \\
\text { Lanreotide Autogel }\end{array}$ & $\begin{array}{l}\text { AcroQoL, } \\
\text { PASQ }\end{array}$ & $\leftrightarrow$ \\
\hline Pasireotide & Bronstein et al. (2016) & 119 & 52 & Uncontrolled & Octreotide LAR & AcroQoL & $\leftrightarrow$ \\
\hline Pegvisomant & Ghigo et al. (2009) $)^{119}$ & 56 & 48 & Uncontrolled & Treatment naïve & $\begin{array}{l}\text { AcroQoL, } \\
\text { SSS }\end{array}$ & $\uparrow \uparrow$ \\
\hline Pegvisomant & Trainer et al. (2009) ${ }^{123}$ & 52 & 40 & Uncontrolled & Octreotide LAR & $\begin{array}{l}\text { AcroQoL, } \\
\text { EQ-5D }\end{array}$ & $\begin{array}{l}\uparrow \uparrow \text { (only } \\
\text { AcroQoL) }\end{array}$ \\
\hline $\begin{array}{l}\text { Pegvisomant weekly } \\
\text { or twice weekly }\end{array}$ & Higham et al. (2009) & 7 & 32 & Controlled & Pegvisomant daily & AcroQoL & $\leftrightarrow$ \\
\hline $\begin{array}{l}\text { Pegvisomant - } \\
\text { Octreotide LAR }\end{array}$ & Trainer et al. (2009) ${ }^{123}$ & 53 & 40 & Uncontrolled & Octreotide LAR & $\begin{array}{l}\text { AcroQoL, } \\
\text { EQ-5D }\end{array}$ & $\begin{array}{l}\uparrow \uparrow \text { (only } \\
\text { AcroQoL) }\end{array}$ \\
\hline $\begin{array}{l}\text { Pegvisomant - } \\
\text { Octreotide LAR }\end{array}$ & Neggers et al. (2008) & 20 & 36 & Controlled & Octreotide LAR & $\begin{array}{l}\text { AcroQoL, } \\
\text { PASQ }\end{array}$ & $\uparrow \uparrow$ \\
\hline $\begin{array}{l}\text { Pegvisomant - } \\
\text { Octreotide LAR }\end{array}$ & Madsen et al. (2011) & 18 & 24 & Controlled & Octreotide LAR & $\begin{array}{l}\text { EQ-5D, } \\
\text { PASQ }\end{array}$ & $\leftrightarrow$ \\
\hline
\end{tabular}

$\uparrow$, improvement in quality of life (QoL) subscale only; $\uparrow \uparrow$, improvement in global QoL; $\leftrightarrow$, no significant change in QoL; CSKSLPP, Cognitive Scale of Kellner's Screening List for Psychosocial Problems; EQ-5D, European quality of life scale; KSQ, Kellner's Symptom Questionnaire (psychological distress and wellbeing): LAR, long-acting release; NHP, Nottingham Health Profile; PASQ, Patient-Assessed Acromegaly Symptom Questionnaire; SF-36, Short-Form Health Survey; SSS, Signs and Symptoms Scale - acromegaly. This table was adapted from Gadelha MR et al., Systemic Complications of Acromegaly and the Impact of the Current Treatment Landscape: An Update, Endocrine Reviews, 2019, Volume 40, Issue 1, Pages 268-332 ${ }^{13}$ by permission of the Endocrine Society.

SF-36, Arthritis Impact Measurement Scales 2 (AIMS2), and AcroQoL questionnaires; $52(90 \%)$ reported musculoskeletal pain, $29(50 \%)$ reported neck pain, $49(84 \%)$ had hip osteoarthritis, and $20(34 \%)$ reported knee osteoarthritis. The SF-36, AIMS2, and AcroQoL scores were lower in patients with musculoskeletal pain. The conclusion was that patients with acromegaly had a significantly higher number of musculoskeletal problems that negatively affect their QoL at different levels ${ }^{136}$. Female patients and those with higher BMI seem to be the most affected ${ }^{137}$. In regard to vertebral fractures, no definite association has been observed with QoL; this is probably because many events are asymptomatic and many are missed unless patients had vertebral x-ray rather than bone densitometry ${ }^{138}$.

\section{Management}

QoL is an important treatment objective besides biochemical remission and tumor control. Close attention to patient perception of wellness is essential and should prompt treatment modifications. Use of specific questionnaires helps to identify areas of improvement and monitor therapy effects. Other interventions such as cognitive behavioral therapy with a technique called "Think healthy and feel the difference" have proven sustained improvement over 9 months. ${ }^{139}$ Moreover, 
physical activity programs ${ }^{140}$, and increased knowledge about the disease from physician-guided discussion groups or patient associations may also help to improve patient's $\mathrm{QoL}^{141}$.

\section{Conclusions}

Recent population studies showed a longer life span for patients with acromegaly; this was most likely due to improvements in treatments, as the average delay in diagnosis seems to be largely unchanged over the decades. Raising awareness of complications of acromegaly even in biochemically controlled disease and introducing adequate screening programs in accordance with Acromegaly Consensus guidelines ${ }^{10,74}$ should improve both morbidity and mortality. Patient-reported outcome and QoL have become essential components of monitoring the disease, and improving QoL is an endpoint of the treatment in itself. Although many questionnaires and scales have been developed, more research is needed to determine how best to measure QoL in patients with pituitary disease in general and with acromegaly in particular.

\section{Acknowledgments}

The authors thank Shirley McCartney, PhD (Oregon Health \& Sciences University Portland, Oregon, USA) for editorial assistance.
1. $\quad$ Melmed S: Acromegaly pathogenesis and treatment. J Clin Invest. 2009; 119(11): 3189-202.

PubMed Abstract | Publisher Full Text | Free Full Text

2. Pivonello R, Auriemma RS, Grasso LFS, et al.: Complications of acromegaly: Cardiovascular, respiratory and metabolic comorbidities. Pituitary. 2017; 20(1) 46-62.

PubMed Abstract | Publisher Full Text

3. Petrossians P, Tichomirowa MA, Stevenaert A, et al.: The Liege Acromegaly Survey (LAS): A new software tool for the study of acromegaly. Ann Endocrinol (Paris). 2012; 73(3): 190-201.

PubMed Abstract | Publisher Full Text

4. Terzolo M, Reimondo G, Berchialla $P$, et al:: Acromegaly is associated with increased cancer risk: A survey in Italy. Endocr Relat Cancer. 2017; 24(9): 495-504.

PubMed Abstract | Publisher Full Text

5. Esposito D, Ragnarsson O, Granfeldt D, et al:: Decreasing mortality and changes in treatment patterns in patients with acromegaly from a nationwide study. Eur J Endocrinol. 2018; 178(5): 459-69. PubMed Abstract | Publisher Full Text | Faculty Opinions Recommendation

6. Dagenais GR, Leong DP, Rangarajan S, et al: Variations in common diseases, hospital admissions, and deaths in middle-aged adults in 21 countries from five continents (PURE): A prospective cohort study. Lancet. 2020; 395(10226): 785-94.

PubMed Abstract | Publisher Full Text | Faculty Opinions Recommendation

7. Bolfi F, Neves AF, Boguszewski CL, et al:: Mortality in acromegaly decreased in the last decade: A systematic review and meta-analysis. Eur J Endocrinol. 2018; 179(1): 59-71.

PubMed Abstract | Publisher Full Text | Faculty Opinions Recommendation

8. Giustina A, Casanueva FF, Cavagnini F, et al.: Diagnosis and treatment of acromegaly complications. J Endocrinol Invest. 2003; 26(12): 1242-7. PubMed Abstract | Publisher Full Text

9. Kunzler LS, Naves LA, Casulari LA: Cognitive-behavioral therapy improves the quality of life of patients with acromegaly. Pituitary. 2018; 21(3): 323-33. PubMed Abstract | Publisher Full Text | Faculty Opinions Recommendation

10. Bonadonna S, Doga M, Gola M, et al:: Diagnosis and treatment of acromegaly and its complications: Consensus guidelines. J Endocrinol Invest. 2005; 28(11 Suppl International): 43-7.

PubMed Abstract

11. Weiss V, Šonka K, Pretl M, et al.: Prevalence of the sleep apnea syndrome in acromegaly population. J Endocrinol Invest. 2000; 23(8): 515-9. PubMed Abstract | Publisher Full Text

12. Webb SM, Badia X: Quality of Life in Acromegaly. Neuroendocrinology. 2016; 103(1): 106-11.

PubMed Abstract | Publisher Full Text

13. Gadelha MR, Kasuki L, Lim DST, et al:: Systemic Complications of Acromegaly and the Impact of the Current Treatment Landscape: An Update. Endocr Rev. 2019; 40(1): 268-332.

PubMed Abstract | Publisher Full Text

14. Colao A, Ferone D, Marzullo $\mathrm{P}$, et al:: Systemic complications of acromegaly: Epidemiology, pathogenesis, and management. Endocr Rev. 2004; 25(1): 102-52. PubMed Abstract | Publisher Full Text

15. Dal J, Feldt-Rasmussen U, Andersen M, et al.: Acromegaly incidence, prevalence, complications and long-term prognosis: A nationwide cohort study. Eur J Endocrinol. 2016; 175(3): 181-90.

PubMed Abstract | Publisher Full Text
16. Chemla D, Attal P, Maione L, et al.: Impact of successful treatment of acromegaly on overnight heart rate variability and sleep apnea. J Clin Endocrinol Metab. 2014; 99(8): 2925-31. PubMed Abstract | Publisher Full Text

17. Vannucci L, Luciani P, Gagliardi E, et al.: Assessment of sleep apnea syndrome in treated acromegalic patients and correlation of its severity with clinical and laboratory parameters. J Endocrinol Invest. 2013; 36(4): 237-42. PubMed Abstract | Publisher Full Text

18. Powlson AS, Gurnell M: Cardiovascular Disease and Sleep-Disordered Breathing in Acromegaly. Neuroendocrinology. 2016; 103(1): 75-85. PubMed Abstract | Publisher Full Text

19. Giustina A, Boni E, Romanelli G, et al.: Cardiopulmonary performance during exercise in acromegaly, and the effects of acute suppression of growth hormone hypersecretion with octreotide. Am J Cardiol. 1995; 75(15): 1042-7. PubMed Abstract | Publisher Full Text

20. Thomas SG, Woodhouse LJ, Pagura SM, et al:: Ventilation threshold as a measure of impaired physical performance in adults with growth hormone excess. Clin Endocrinol (Oxf). 2002; 56(3): 351-8.

PubMed Abstract | Publisher Full Text

21. Yilmaz F, Ozyildirim S, Talay F, et al:: Obstructive sleep apnea: a risk factor for cardiovascular disease. Cardiol J. 2007; 14(2): 534-7. PubMed Abstract | Publisher Full Text

22. Yaggi HK, Mittleman MA, Bravata DM, et al.: Reducing cardiovascular risk through treatment of obstructive sleep apnea: 2 methodological approaches. Am Heart J. 2016; 172: 135-43.

PubMed Abstract | Publisher Full Text | Free Full Text

23. Wang $X$, Ouyang $Y$, Wang $Z$, et al: Obstructive sleep apnea and risk of cardiovascular disease and all-cause mortality: A meta-analysis of prospective cohort studies. Int J Cardiol. 2013; 169(3): 207-14. PubMed Abstract | Publisher Full Text

24. Maione L, Brue T, Beckers A, et al:: Changes in the management and comorbidities of acromegaly over three decades: The French Acromegaly Registry. Eur J Endocrinol. 2017; 176(5): 645-55. PubMed Abstract | Publisher Full Text

25. Ritvonen E, Löyttyniemi E, Jaatinen P, et al:: Mortality in acromegaly: A 20year follow-up study. Endocr Relat Cancer. 2016; 23(6): 469-80. PubMed Abstract | Publisher Full Text | Faculty Opinions Recommendation

26. Brody JS, Fisher AB, Gocmen A, et al:: Acromegalic pneumonomegaly: Lung growth in the adult. J Clin Invest. 1970; 49(6): 1051-60. PubMed Abstract | Publisher Full Text | Free Full Text

27. Benfante A, Ciresi A, Bellia M, et al:: Early lung function abnormalities in acromegaly. Lung. 2015; 193(3): 393-9. PubMled Abstract | Publisher Full Text

28. Murrant NJ, Gatland DJ: Respiratory problems in acromegaly. $J$ Laryngol Otol. 1990; 104(1): 52-5. PubMed Abstract | Publisher Full Text

29. Kamenicky $\mathrm{P}$, Blanchard $\mathrm{A}$, Frank $\mathrm{M}$, et al.: Body fluid expansion in acromegaly is related to enhanced epithelial sodium channel (ENaC) activity. J Clin Endocrinol Metab. 2011; 96(7): 2127-35. PubMed Abstract | Publisher Full Text | Faculty Opinions Recommendation

30. Kamenický P, Mazziotti G, Lombès M, et al:: Growth hormone, insulin-like growth factor-1, and the kidney: Pathophysiological and clinical implications. Endocr Rev. 2014; 35(2): 234-81.

PubMed Abstract | Publisher Full Text

31. Camilo GB, Carvalho ARS, Guimarães ARM, et al.: Computed tomography 
airway lumen volumetry in patients with acromegaly: Association with growth hormone levels and lung function. J Med Imaging Radiat Oncol. 2017; 61(5): 591-9. PubMed Abstract | Publisher Full Text

32. Lobie PE, García-Aragón J, et al.: Cellular localization of the growth hormone binding protein in the rat. Endocrinology. 1992; 130(5): 3057-65. PubMed Abstract | Publisher Full Text

33. Noveral JP, Bhala A, Hintz RL, et al.: Insulin-like growth factor axis in airway smooth muscle cells. Am J Physiol. 1994; 267(6 Pt 1): L761-L765. PubMed Abstract | Publisher Full Text

34. Donnelly PM, Grunstein RR, Peat JK, et al.: Large lungs and growth hormone: An increased alveolar number? Eur Respir J. 1995; 8(6): 938-47. PubMed Abstract

35. Evans CC, Hipkin LJ, Murray GM: Pulmonary function in acromegaly. Thorax 1977; 32(3): 322-7.

PubMed Abstract | Publisher Full Text | Free Full Text

36. Camilo GB, Carvalho ARS, Machado DC, et al:: Correlations between forced oscillation technique parameters and pulmonary densitovolumetry values in patients with acromegaly. Braz J Med Biol Res. 2015; 48(10): 877-85. PubMed Abstract | Publisher Full Text | Free Full Text

37. Camilo GB, Carvalho ARS, Machado DC, et al:: CT pulmonary densitovolumetry in patients with acromegaly: A comparison between active disease and controlled disease. Br J Radiol. 2015; 88(1054): 20150315. PubMed Abstract | Publisher Full Text | Free Full Text

38. Camilo GB, Guimarães FS, Silva DPG, et al:: Pulmonary function testing and chest tomography in patients with acromegaly. Multidiscip Respir Med. 2013; 8(1): 70 .

PubMed Abstract | Publisher Full Text | Free Full Text

39. Zhang Z, Li Q, He W, et al:: The comprehensive impact on human body induced by resolution of growth hormone excess. Eur J Endocrinol. 2018; 178(4): 365-75.

PubMed Abstract | Publisher Full Text | Faculty Opinions Recommendation

40. Mastaglia FL, Barwick DD, Hall R: Myopathy in Acromegaly. Lancet. 1970 2(7679): 907-9.

PubMed Abstract | Publisher Full Text

41. Khaleeli AA, Levy RD, Edwards RH, et al:: The neuromuscular features of acromegaly: A clinical and pathological study. J Neurol Neurosurg Psychiatry. 1984; 47(9): 1009-15.

PubMed Abstract | Publisher Full Text | Free Full Text

42. Attal P, Claes V, Bobin S, et al.: Growth hormone excess and sternohyoid muscle mechanics in rats. Eur Respir J. 2009; 34(4): 967-74.

PubMed Abstract | Publisher Full Text

43. García-Río F, Pino JM, et al:: Reduction of Lung Distensibility in Acromegaly after Suppression of Growth Hormone Hypersecretion. Am J Respir Crit Care Med. 2001; 164(5): 852-7.

PubMed Abstract | Publisher Full Text

44. Trotman-Dickenson B, Weetman AP, Hughes JM: Upper airflow obstruction and pulmonary function in acromegaly: Relationship to disease activity. $Q J$ Med. 1991: 79(290): $527-38$

PubMed Abstract

45. Yalin AS SS, Temizkan S, Gunes M, et al.: Evaluation of respiratory function in acromegalic patient. Endocrine Abstracts. 2010; 22: 410.

Reference Source

46. Saler T, Ucak S, Yesim T, et al.: Diffusing Lung Capacity of Carbon Monoxide/ Alveolar Volume as an Index for Evaluating Diffusing Capacity of the Acromegalic Lung. The Endocrinologist. 2009; 19(6): 288-90. Publisher Full Tex

47. Gläser S, Friedrich N, Ewert R, et al:: Association between serum insulin-like growth factor (IGF) I and IGF binding protein-3 and lung function. $J$ Clin Endocrinol Metab. 2009; 94(7): 2452-8. PubMed Abstract | Publisher Full Text

48. Siafakas NM, Sigalas J, Filaditaki B, et al.: Small airway function in acromegaly. Bull Eur Physiopathol Respir. 1987; 23(4): 329-34.

PubMed Abstract

49. Rodrigues MP, Naves LA, Viegas CA, et al.: Prevalence of lung structure abnormalities in patients with acromegaly and their relationship with gas exchange: Cross-sectional analytical study with a control group. Sao Paulo Med J. 2015; 133(5): 394-400

PubMed Abstract | Publisher Full Tex

50. Veasey SC, Rosen IM: Obstructive Sleep Apnea in Adults. N Engl J Med 2019; 380(15): 1442-9.

PubMed Abstract | Publisher Full Text | Faculty Opinions Recommendation

51. Saaresranta T, Polo O: Hormones and breathing. Chest. 2002; 122(6): 2165-82. PubMed Abstract | Publisher Full Text

52. Chanson P, Timsit J, Benoit O, et al: Rapid Improvement in Sleep Apnoea of Acromegaly After Short-Term Treatment With Somatostatin Analogue SMS 201-995. Lancet. 1986; 327(8492): 1270-1.

PubMed Abstract | Publisher Full Text

53. Grunstein RR, Ho KY, Sullivan CE: Sleep apnea in acromegaly. Ann Intern Med. 1991; 115(7): 527-32.

PubMed Abstract | Publisher Full Tex

54. Herrmann BL, Wessendorf TE, Ajaj W, et al.: Effects of octreotide on sleep apnoea and tongue volume (magnetic resonance imaging) in patients with acromegaly. Eur J Endocrinol. 2004; 151(3): 309-15.

PubMed Abstract | Publisher Full Text

55. Wolters TLC, Roerink SHPP, Drenthen LCA, et al:: The Course of Obstructive Sleep Apnea Syndrome in Patients With Acromegaly During Treatment. J Clin Endocrinol Metab. 2020; 105(1): dgz050.

PubMed Abstract | Publisher Full Text | Faculty Opinions Recommendation

56. Grunstein RR, Ho KY, Berthon-Jones M, et al:: Central sleep apnea is associated with increased ventilatory response to carbon dioxide and hypersecretion of growth hormone in patients with acromegaly. Am J Respir Crit Care Med. 1994 150(2): 496-502.

PubMed Abstract | Publisher Full Text

57. Chennaoui M, Léger D, Gomez-Merino D: Sleep and the GH/IGF-1 axis: Consequences and countermeasures of sleep loss/disorders. Sleep Med Rev. 2020; 49: 101223.

PubMed Abstract | Publisher Full Text | Faculty Opinions Recommendation

58. Bhasin S, Brito JP, Cunningham GR, et al:: Testosterone Therapy in Men With Hypogonadism: An Endocrine Society Clinical Practice Guideline. J Clin Endocrinol Metab. 2018; 103(5): 1715-44

PubMed Abstract | Publisher Full Text | Faculty Opinions Recommendation

59. Attal $P$, Chanson $P$, et al.: Endocrine aspects of obstructive sleep apnea. J Clin Endocrinol Metab. 2010; 95(2): 483-95. PubMed Abstract | Publisher Full Tex

60. Wennberg A, Lorusso R, Dassie F, et al:: Sleep disorders and cognitive dysfunction in acromegaly. Endocrine. 2019; 66(3): 634-641. PubMed Abstract | Publisher Full Text | Faculty Opinions Recommendation

61. Davì MV, Giustina A: Sleep apnea in acromegaly: A review on prevalence, pathogenetic aspects and treatment. Expert Rev Endocrinol Metab. 2012; 7(1): $55-62$.

PubMed Abstract | Publisher Full Text

62. Pekkarinen T, Partinen M, Pelkonen R, et al:: Sleep Apnoea and Daytime Sleepiness in Acromegaly: Relationship to Endocrinological Factors. Clin Endocrinol (Oxf). 1987; 27(6): 649-54. PubMed Abstract | Publisher Full Tex

63. Rosenow F, Reuter S, Deuss $U$, et al:: Sleep apnoea in treated acromegaly: Relative frequency and predisposing factors. Clin Endocrinol (Oxf). 1996; 45(5): $563-9$.

PubMed Abstract | Publisher Full Tex

64. Vouzouneraki K, Franklin KA, Forsgren M, et al.: Temporal relationship of sleep apnea and acromegaly: A nationwide study. Endocrine. 2018; 62(2): 456-63. PubMed Abstract | Publisher Full Text | Free Full Text |

Faculty Opinions Recommendation

65. Kapur VK, Auckley DH, Chowdhuri S, et al.: Clinical Practice Guideline for Diagnostic Testing for Adult Obstructive Sleep Apnea: An American Academy of Sleep Medicine Clinical Practice Guideline. J Clin Sleep Med. 2017; 13(3): 479-504.

PubMed Abstract | Publisher Full Text | Free Full Text

66. Roemmler J, Gutt B, Fischer R, et al.: Elevated incidence of sleep apnoea in acromegaly - correlation to disease activity. Sleep Breath. 2012; 16(4): 1247-53. PublMed Abstract | Publisher Full Text

67. Störmann S, Gutt B, Roemmler-Zehrer J, et al: Assessment of lung function in a large cohort of patients with acromegaly. Eur J Endocrinol. 2017; 177(1): 15-23. PubMed Abstract | Publisher Full Text

68. Parolin M, Dassie F, Alessio L, et al:: Obstructive Sleep Apnea in Acromegaly and the Effect of Treatment: A Systematic Review and Meta-Analysis. J Clin Endocrinol Metab. 2020; 105(3): dgz116.

PubMed Abstract | Publisher Full Text | Faculty Opinions Recommendation

69. Berg C, Wessendorf TE, Mortsch F, et al:: Influence of disease control with pegvisomant on sleep apnoea and tongue volume in patients with active acromegaly. Eur J Endocrinol. 2009; 161(6): 829-35.

PubMed Abstract | Publisher Full Text

70. Grunstein RR, Ho KK, Sullivan CE: Effect of octreotide, a somatostatin analog, on sleep apnea in patients with acromegaly. Ann Intern Med. 1994; 121(7): on sleep $478-83$.

PubMed Abstract | Publisher Full Text

71. Al Lawati NM, Patel SR, Ayas NT: Epidemiology, risk factors, and consequences of obstructive sleep apnea and short sleep duration. Prog Cardiovasc Dis. 2009; 51(4): 285-93

PubMed Abstract | Publisher Full Text

72. Annamalai AK, Webb A, Kandasamy N, et al:: A comprehensive study of clinical, biochemical, radiological, vascular, cardiac, and sleep parameters in an unselected cohort of patients with acromegaly undergoing presurgical somatostatin receptor ligand therapy. J Clin Endocrinol Metab. 2013; 98(3): 1040-50.

PubMed Abstract | Publisher Full Text | Faculty Opinions Recommendation

73. Katznelson L, Laws ER Jr, Melmed S, et al:: Acromegaly: An endocrine society clinical practice guideline. J Clin Endocrinol Metab. 2014; 99(11): 3933-51. PubMed Abstract | Publisher Full Text

74. Giustina A, Barkan A, Beckers A, et al:: A Consensus on the Diagnosis and Treatment of Acromegaly Comorbidities: An Update. J Clin Endocrinol Metab. 2020; 105(4): dgz096.

PubMed Abstract | Publisher Full Text 
75. Badia X, Webb SM, Prieto L, et al:: Acromegaly Quality of Life Questionnaire (AcroQoL). Health Qual Life Outcomes. 2004; 2: 13. PubMed Abstract | Publisher Full Text | Free Full Text

76. Liu S, Adelman DT, Xu Y, et al:: Patient-centered assessment on disease burden, quality of life, and treatment satisfaction associated with acromegaly. $J$ Investig Med. 2018; 66(3): 653-60. PubMed Abstract | Publisher Full Text | Faculty Opinions Recommendation

77. Ben-Shlomo A, Sheppard MC, Stephens JM, et al.: Clinical, quality of life, and economic value of acromegaly disease control. Pituitary. 2011; 14(3): 284-94. PubMed Abstract | Publisher Full Text | Free Full Text | Faculty Opinions Recommendation

78. Cannavò S, Condurso R, Ragonese M, et al:: Increased prevalence of restless legs syndrome in patients with acromegaly and effects on quality of life assessed by Acro-QoL. Pituitary. 2011; 14(4): 328-34. PubMed Abstract | Publisher Full Text

79. Yedinak CG, Fleseriu M: Self-perception of cognitive function among patients with active acromegaly, controlled acromegaly, and non-functional pituitary adenoma: A pilot study. Endocrine. 2014; 46(3): 585-93. PubMed Abstract | Publisher Full Text

80. N Jawiarczyk-Przybyłowska A, Szcześniak D, Ciułkowicz M, et al:: Importance of IIIness Acceptance Among Other Factors Affecting Quality of Life in Acromegaly. Front Endocrinol (Lausanne). 2020; 10: 899. PubMed Abstract | Publisher Full Text | Free Full Text Faculty Opinions Recommendation

81. Siegel S, Streetz-van der Werf C, Schott JS, et al:: Diagnostic delay is associated with psychosocial impairment in acromegaly. Pituitary. 2013; 16(4): 507-14. PubMed Abstract | Publisher Full Text

82. Rowles SV Prieto L, Badia X et al: Quality of Life (QOL) in Patients with Acromegaly Is Severely Impaired: Use of a Novel Measure of QOL: Acromegaly Quality of Life Questionnaire. J Clin Endocrinol Metab. 2005; 90(6): 3337-41. PubMed Abstract | Publisher Full Text

83. Kellner R: A symptom questionnaire. J Clin Psychiatry. 1987; 48(7): 268-74. PubMed Abstract

84. Fava GA, Kellner R, Perini Gl, et al.: Italian validation of the Symptom Rating Test (SRT) and Symptom Questionnaire (SQ). Can J Psychiatry. 1983; 28(2): $117-23$.

PubMed Abstract | Publisher Full Text

85. Trainer PJ, Drake WM, Katznelson L, et al:: Treatment of Acromegaly with the Growth Hormone-Receptor Antagonist Pegvisomant. N Engl J Med. 2000; 342(16): 1171-7.

PubMed Abstract | Publisher Full Text

86. van der Lely AJ, Hutson RK, Trainer PJ, et al.: Long-term treatment of acromegaly with pegvisomant, a growth hormone receptor antagonist. Lancet. 2001 358(9295): 1754-9.

PubMed Abstract | Publisher Full Text

87. McHorney CA, Ware JE Jr, Raczek AE: The MOS 36-Item Short-Form Health Survey (SF-36): II. Psychometric and clinical tests of validity in measuring physical and mental health constructs. Med Care. 1993; 31(3): 247-63. PubMed Abstract | Publisher Full Text

88. McHorney CA, Ware Jr JE, Rachel Lu JF, et al.: The MOS 36-Item Short-Form Health Survey (SF-36): III. Tests of Data Quality, Scaling Assumptions, and Reliability Across Diverse Patient Groups. Med Care. 1994; 32(1): 40-66. PubMed Abstract | Publisher Full Text

89. Russo J, Trujillo CA, Wingerson D, et al:: The MOS 36-Item Short Form Health Survey: Reliability, validity, and preliminary findings in schizophrenic outpatients. Med Care. 1998; 36(5): 752-6.

PubMed Abstract | Publisher Full Text

90. van der Klaauw AA, Kars M, Biermasz NR, et al:: Disease-specific impairments in quality of life during long-term follow-up of patients with different pituitary adenomas. Clin Endocrinol (Oxf). 2008; 69(5): 775-84. PubMed Abstract | Publisher Full Text

91. Smets EM, Garssen B, Bonke B, et al.: The multidimensional Fatigue Inventory (MFI) psychometric qualities of an instrument to assess fatigue. J Psychosom Res. 1995; 39(3): 315-25.

PubMed Abstract | Publisher Full Text

92. Hunt SM, McKenna SP, McEwen J, et al: A quantitative approach to perceived health status: A validation study. J Epidemiol Community Health. 1980; 34(4): $281-6$.

PubMed Abstract | Publisher Full Text | Free Full Text

93. Hunt SM, McKenna SP, McEwen J, et al:: The Nottingham health profile: Subjective health status and medical consultations. Soc Sci Med A. 1981; 15(3 Pt 1): 221-9.

PubMed Abstract | Publisher Full Text

94. Kauppinen-Mäkelin R, Sane T, Sintonen $\mathrm{H}$, et al.: Quality of life in treated patients with acromegaly. J Clin Endocrinol Metab. 2006; 91(10): 3891-6. PubMed Abstract | Publisher Full Text

95. Grossi E, Groth N, Mosconi P, et al.: Development and validation of the short version of the Psychological General Well-Being Index (PGWB-S). Health Qual Life Outcomes. 2006; 4: 88 PubMed Abstract | Publisher Full Text | Free Full Text

96. Wassenaar MJE, Biermasz NR, Kloppenburg M, et al:: Clinical osteoarthritis predicts physical and psychological QoL in acromegaly patients. Growth Horm
IGF Res. 2010; 20(3): 226-33.

PubMed Abstract | Publisher Full Tex

97. Zigmond AS, Snaith RP: The Hospital Anxiety and Depression Scale. Acta Psychiatr Scand. 1983; 67(6): 361-70.

PubMed Abstract | Publisher Full Text

98. Webb SM, Badia X, Surinach NL, et al.: Validity and clinical applicability of the acromegaly quality of life questionnaire, AcroQoL: A 6-month prospective study. Eur J Endocrinol. 2006; 155(2): 269-77.

PubMed Abstract | Publisher Full Text

99. Fleseriu M, Fogelfeld L, Gordon MB, et al.: Development of a novel patientreported measure for acromegaly: The Acro-TSQ. Pituitary. 2019; 22(6): 581-93. PubMed Abstract | Publisher Full Text | Free Full Text

100. Fleseriu M, Fogelfeld L, Gordon MB, et al:: An evaluation of the Acromegaly Treatment Satisfaction Questionnaire (Acro-TSQ) in adult patients with acromegaly, including correlations with other patient-reported outcome measures: Data from two large multicenter international studies. Pituitary. 2020; 23(4): 347-358.

PubMed Abstract | Publisher Full Text | Free Full Text

101. Geraedts VJ, Andela CD, Stalla GK, et al.: Predictors of Quality of Life in Acromegaly: No Consensus on Biochemical Parameters. Front Endocrinol (Lausanne). 2017: 8: 40. PubMed Abstract | Publisher Full Text | Free Full Text

102. L Lenders NF, McCormack Al, Ho KKY: MANAGEMENT OF ENDOCRINE DISEASE: Does gender matter in the management of acromegaly? Eur $J$ Endocrinol. 2020; 182(5): R67-R82.

PubMed Abstract | Publisher Full Text | Faculty Opinions Recommendation

103. Ambrosio MR, Gagliardi I, Chiloiro S, et al.: Acromegaly in the elderly patients. Endocrine. 2020; 68(1): 16-31. PubMed Abstract | Publisher Full Text

104. Wolters TLC, Roerink SHPP, Sterenborg RBTM, et al:: The effect of treatment on quality of life in patients with acromegaly: A prospective study. Eur $J$ Endocrinol. 2020; 182(3): 319-31.

PubMed Abstract | Publisher Full Text | Faculty Opinions Recommendation

105. Paisley AN, Rowles SV, Roberts ME, et al.: Treatment of acromegaly improves quality of life, measured by AcroQol. Clin Endocrinol (Oxf). 2007; 67(3): 358-62. PubMed Abstract | Publisher Full Text

106. CTseng FY, Chen ST, Chen JF, et al.: Correlations of clinical parameters with quality of life in patients with acromegaly: Taiwan Acromegaly Registry. $J$ Formos Med Assoc. 2019; 118(11): 1488-93.

PubMed Abstract | Publisher Full Text | Faculty Opinions Recommendation

107. Trepp R, Everts R, Stettler C, et al:: Assessment of quality of life in patients with uncontrolled vs. controlled acromegaly using the Acromegaly Quality of Life Questionnaire (AcroQoL). Clin Endocrinol (Oxf). 2005; 63(1): 103-10. PubMed Abstract | Publisher Full Text

108. Biermasz NR, van Thiel SW, Pereira AM, et al:: Decreased quality of life in patients with acromegaly despite long-term cure of growth hormone excess. J Clin Endocrinol Metab. 2004; 89(11): 5369-76. PubMed Abstract | Publisher Full Text

109. Biermasz NR, Pereira AM, Smit JWA, et al.: Morbidity after Long-Term Remission for Acromegaly: Persisting Joint-Related Complaints Cause Reduced Quality of Life. J Clin Endocrinol Metab. 2005; 90(5): 2731-9. PubMed Abstract | Publisher Full Text

110. W Waddle MR, Oudenhoven MD, Farin CV, et al:: Impacts of Surgery on Symptom Burden and Quality of Life in Pituitary Tumor Patients in the Subacute Post-operative Period. Front Oncol. 2019; 9: 299. PubMed Abstract | Publisher Full Text | Free Full Text | Faculty Opinions Recommendation

111. Matta MP, Couture E, Cazals L, et al:: Impaired quality of life of patients with acromegaly: Control of GH/IGF-I excess improves psychological subscale appearance. Eur J Endocrinol. 2008; 158(3): 305-10. PublMed Abstract | Publisher Full Text

112. Rubeck KZ, Madsen M, Andreasen CM, et al:: Conventional and novel biomarkers of treatment outcome in patients with acromegaly: Discordant results after somatostatin analog treatment compared with surgery. Eur $J$ Endocrinol. 2010; 163(5): 717-26. PubMed Abstract | Publisher Full Text

113. Sonino N, Scarpa E, Paoletta A, et al.: Slow-Release Lanreotide Treatment in Acromegaly: Effects on Quality of Life. Psychother Psychosom. 1999; 68(3): 165-7. PubMed Abstract | Publisher Full Text

114. Lombardi G, Minuto F, Tamburrano G, et al:: Efficacy of the new long-acting formulation of lanreotide (lanreotide Autogel) in somatostatin analogue-naive patients with acromegaly. J Endocrinol Invest. 2009; 32(3): 202-9. PubMed Abstract | Publisher Full Text

115. Caron PJ, Bevan JS, Petersenn S, et al.: Effects of lanreotide Autogel primary therapy on symptoms and quality-of-life in acromegaly: Data from the PRIMARYS study. Pituitary. 2016; 19(2): 149-57. PubMed Abstract | Publisher Full Text | Free Full Text

116. Schopohl J, Strasburger CJ, Caird D, et al:: Efficacy and Acceptability of Lanreotide Autogel ${ }^{\circledast} 120 \mathrm{mg}$ at Different Dose Intervals in Patients with Acromegaly Previously Treated with Octreotide LAR. Exp Clin Endocrinol Diabetes. 2011; 119(3): 156-62. PubMed Abstract | Publisher Full Text 
117. Mangupli $R$, Camperos $P$, Webb SM: Biochemical and quality of life responses to octreotide-LAR in acromegaly. Pituitary. 2014; 17(6): 495-9. PubMed Abstract | Publisher Full Text

118. Chin SO, Chung $\mathrm{CH}$, Chung YS, et al:: Change in quality of life in patients with acromegaly after treatment with octreotide LAR: First application of AcroQoL in Korea. BMJ Open. 2015; 5(6): e006898-e006898. PubMed Abstract | Publisher Full Text | Free Full Text

119. Ghigo E, Biller BMK, Colao A, et al:: Comparison of pegvisomant and longacting octreotide in patients with acromegaly naïve to radiation and medical therapy. J Endocrinol Invest. 2009; 32(11): 924-33. PubMed Abstract | Publisher Full Text

120. Biermasz NR, van den Oever NC, Frolich M, et al:: Sandostatin LAR in acromegaly: A 6-week injection interval suppresses GH secretion as effectively as a 4-week interval. Clin Endocrinol (Oxf). 2003; 58(3): 288-95. PubMed Abstract | Publisher Full Text

121. D Dal J, Klose M, Heck A, et al:: Targeting either GH or IGF-I during somatostatin analogue treatment in patients with acromegaly: A randomized multicentre study. Eur J Endocrinol. 2018; 178(1): 65-74. PubMed Abstract | Publisher Full Text | Faculty Opinions Recommendation

122. Bronstein MD, Fleseriu M, Neggers S, et al:: Switching patients with acromegaly from octreotide to pasireotide improves biochemical control: Crossover extension to a randomized, double-blind, Phase III study. BMC Endocr Disord. 2016; 16: 16.

PubMed Abstract | Publisher Full Text | Free Full Text

123. Trainer PJ, Ezzat S, D'Souza GA, et al:: A randomized, controlled, multicentre trial comparing pegvisomant alone with combination therapy of pegvisomant and long-acting octreotide in patients with acromegaly. Clin Endocrinol (Oxf). 2009; 71(4): 549-57.

PubMed Abstract | Publisher Full Text | Faculty Opinions Recommendation

124. Neggers SJCMM, van Aken MO, de Herder WW, et al.: Quality of Life in Acromegalic Patients during Long-Term Somatostatin Analog Treatment with and without Pegvisomant. J Clin Endocrinol Metab. 2008; 93(10): 3853-9. PubMed Abstract | Publisher Full Text

125. Madsen M, Poulsen PL, Orskov H, et al.: Cotreatment with pegvisomant and a somatostatin analog (SA) in SA-responsive acromegalic patients. J Clin Endocrinol Metab. 2011; 96(8): 2405-13 PubMed Abstract | Publisher Full Text | Faculty Opinions Recommendation

126. D Postma MR, Netea-Maier RT, van den Berg G, et al:: Quality of life is impaired in association with the need for prolonged postoperative therapy by somatostatin analogs in patients with acromegaly. Eur J Endocrinol. 2012; 166(4): 585-92.

PubMed Abstract | Publisher Full Text | Faculty Opinions Recommendation

127. Fleseriu M, Molitch M, Dreval A, et al.: Symptom Burden and Impact of Treatment in Patients with Acromegaly Treated with Injectable Somatostatin Receptor Ligands. Poster presentation presented at 18th Congress of the European Neuroendocrine Association; Wrocław, Poland. 2018; 17-20.

128. Higham CE, Thomas JDJ, Bidlingmaier M, et al:: Successful use of weekly pegvisomant administration in patients with acromegaly. Eur $J$ Endocrinol. 2009; 161(1): 21-5.

PubMed Abstract | Publisher Full Text

129. Giustina A, Arnaldi G, Bogazzi F, et al.: Pegvisomant in acromegaly: An update.
J Endocrinol Invest. 2017; 40(6): 577-89.

PubMled Abstract | Publisher Full Text | Free Full Text

130. van der Klaauw AA, Biermasz NR, Hoftijzer HC, et al:: Previous radiotherapy negatively influences quality of life during 4 years of follow-up in patients cured from acromegaly. Clin Endocrinol (Oxf). 2008; 69(1): 123-8. PubMed Abstract | Publisher Full Text

131. Wexler T, Gunnell L, Omer Z, et al:: Growth Hormone Deficiency Is Associated with Decreased Quality of Life in Patients with Prior Acromegaly. J Clin Endocrinol Metab. 2009; 94(7): 2471-7. PubMed Abstract | Publisher Full Text | Free Full Text

132. Colao A, Cannavò $S$, Marzullo $P$, et al: Twelve months of treatment with octreotideLAR reduces joint thickness in acromegaly. Eur J Endocrinol. 2003; 148(1): 31-8. PubMed Abstract | Publisher Full Text

133. Dons RF, Rosselet P, Pastakia B, et al:: Arthropathy in acromegalic patients before and after treatment: A long-term follow-up study. Clin Endocrinol (Oxf). 1988; 28(5): 515-24. PubMed Abstract | Publisher Full Text

134. Colao A, Grasso LFS, Di Cera M, et al: Association between biochemical control and comorbidities in patients with acromegaly: An Italian longitudina retrospective chart review study. J Endocrinol Invest. 2020; 43(4): 529-38. PubMed Abstract | Publisher Full Text | Free Full Text | Faculty Opinions Recommendation

135. Claessen KMJA, Ramautar SR, Pereira AM, et al:: Progression of acromegalic arthropathy despite long-term biochemical control: A prospective, radiological study. Eur J Endocrinol. 2012; 167(2): 235-44. PubMed Abstract | Publisher Full Text

136. Miller A, Doll H, David J, et al.: Impact of musculoskeletal disease on quality of life in long-standing acromegaly. Eur J Endocrinol. 2008; 158(5): 587-93. PubMed Abstract | Publisher Full Text

137. Fatti LM, Cangiano B, Vitale G, et al:: Arthropathy in acromegaly: A questionnaire-based estimation of motor disability and its relation with quality of life and work productivity. Pituitary. 2019; 22(5): 552-60. PubMed Abstract | Publisher Full Text | Faculty Opinions Recommendation

138. Wassenaar MJE, Biermasz NR, Hamdy NAT, et al.: High prevalence of vertebral fractures despite normal bone mineral density in patients with longterm controlled acromegaly. Eur J Endocrinol. 2011; 164(4): 475-83. PubMed Abstract | Publisher Full Text | Faculty Opinions Recommendation

139. Kunzler LS, Naves LA, Casulari LA: The Effect of Cognitive-Behaviora Therapy on Acromegalics After a 9-Month Follow-Up. Front Endocrinol (Lausanne). 2019; 10: 380.

PubMed Abstract | Publisher Full Text | Free Full Text | Faculty Opinions Recommendation

140. Lima TRL, Kasuki L, Gadelha M, et al.: Physical exercise improves functional capacity and quality of life in patients with acromegaly: A 12-week follow-up study. Endocrine. 2019; 66(2): 301-9. PubMed Abstract | Publisher Full Text | Faculty Opinions Recommendation

141. Albarel F, Elaraki F, Delemer B: Daily life, needs and expectations of patients with acromegaly in France: An on-line survey. Ann Endocrinol (Paris). 2019; 80(2): 110-6.

PubMed Abstract | Publisher Full Text | Faculty Opinions Recommendation 


\section{Open Peer Review}

\section{Current Peer Review Status:}

\section{Editorial Note on the Review Process}

Faculty Reviews are review articles written by the prestigious Members of Faculty Opinions. The articles are commissioned and peer reviewed before publication to ensure that the final, published version is comprehensive and accessible. The reviewers who approved the final version are listed with their names and affiliations.

\section{The reviewers who approved this article are:}

\section{Version 1}

\section{Lucio Vilar}

Departamento de Endocrinologia, Hospital de Clínicas, Universidade Federal de Pernambuco (UFPE), Recife, PE, Brazil

Competing Interests: No competing interests were disclosed.

\section{Sebastian J Neggers} Rotterdam Pituitary Centre, Erasmus University MC, Rotterdam, The Netherlands

Competing Interests: No competing interests were disclosed.

\section{Salvatore Cannavo}

Endocrine Unit, University Hospital G. Martino, Messina, Italy Competing Interests: No competing interests were disclosed.

The benefits of publishing with F1000Research:

- Your article is published within days, with no editorial bias

- You can publish traditional articles, null/negative results, case reports, data notes and more

- The peer review process is transparent and collaborative

- Your article is indexed in PubMed after passing peer review

- Dedicated customer support at every stage

For pre-submission enquiries, contact research@f1000.com 